\title{
Examining forest cover change and deforestation drivers in Taunggyi District, Shan State, Myanmar
}

\author{
Prashanti Sharma $^{1}$ (D) Rajesh Bahadur Thapa ${ }^{1} \cdot$ Mir Abdul Matin $^{1}$
}

Received: 20 November 2018 / Accepted: 28 July 2019 / Published online: 5 August 2019

(c) The Author(s) 2019

\begin{abstract}
Myanmar has been experiencing a significant amount of deforestation and forest degradation in recent years. Being a developing country, people are heavily dependent on its forest for sustenance and livelihood. This study examines a methodology to identify potential drivers and their relative significance for deforestation. The study was tested in one of the districts but could be applied in other areas of the country. The forest and non-forest land cover maps from the Japan Aerospace Exploration Agency (JAXA) for the years 2008 and 2016 were used in the study. It was derived that $46.54 \%$ of study area is still covered with forest, but there has been a significant decrease in forest area by $7.29 \%$ between the years 2008 and 2016. We examined a number of spatially explicit potential drivers of deforestation such as infrastructure, elevation, slope, deforested land, and population. As informed prevention awareness of deforestation, we projected future forest conditions using a cellular automation modeling technique for the years 2020, 2025 and 2030. We found that major physical and socioeconomic driving factors of deforestation such as proximity to infrastructure (reservoirs and roads), certain elevation levels, slope, proximity to previously deforested area and population density are strongly associated with neighborhood deforestation. The future projection showed a decrease in forest area by $13.8 \%$ from 2016 to 2030. This work therefore provides crucial information on forest landscape for forest management in the district. The projective scenario of study area generated by the model highlights the need for forest conservation and planning while addressing the key drivers of deforestation, giving direction for future potential areas of REDD+ implementation in the region.
\end{abstract}

Keywords Land cover change $\cdot$ Deforestation $\cdot$ Myanmar $\cdot$ Weights of evidence $\cdot$ REDD+

Prashanti Sharma

prashanti.sharma222@gmail.com

1 International Centre for Integrated Mountain Development (ICIMOD), Khumaltar, Lalitpur, G.P.O.

Box 3226, Kathmandu, Nepal 


\section{Introduction}

Forests have extraordinary and far-reaching contribution for the wellbeing of humankind and biodiversity. It plays a fundamental role in providing food security, combating rural poverty and providing livelihood opportunities to a large population of forest dependent community. Forests provide a range of long-term ecosystem services like clean air and water, serve as carbon sinks and store, conserve biodiversity and mitigate climate change (FAO 2015). Globally, the world's natural forest area has undergone major change since 2010 by a decrease of 6.5 million ha per year (FAO 2015). Currently, deforestation and forest degradation is considered to be the second major contributor of greenhouse gas (GHG) emissions after the fossils fuels (IPCC 2008). Subsequently, Myanmar, a country with about $45 \%$ of land covered with forests supporting variety of distinct vegetation composition and wide range of faunal diversity, is undergoing unprecedented changes in forest quality and quantity in the recent years. Annually, 546 thousand ha of forest is estimated to be deforested in Myanmar and has been ranked to have the third highest forest loss in the world after Brazil and Indonesia (FAO 2015). Such substantial loss may bring devastating outcomes to human lives and the overall ecosystem in the country. With decreasing forest and population growing by one million annually, pressure for increase in food and firewood consumption is inevitable. Myanmar has increased 7.73 million ha of agricultural field from 1990 to 2011 which is the direct result of change in land use pattern. Shan State, a state covering 1/4th of Myanmar, had the largest net forest loss of $5647.7 \mathrm{~km}^{2}$, for the year 2001-2010 (Wang and Myint 2016) and was responsible for emitting 6.86 million tons of carbon annually (FAO/RECOFTC 2016).

To reduce the effect of GHG emissions from forests at the same time, contribute to reducing poverty and sustainable development, "Reducing emissions from deforestation and forest degradation" (REDD+) developed by parties to UNFCCC has been introduced in many developing countries including Myanmar. The Measurement, Reporting and Verification (MRV) activities of REDD+ include timely measurement of forest stocks, monitoring of forest loss and estimating forest-related emissions, among a few. For this, earth observation and geospatial technologies can provide spatially explicit datasets and products useful for monitoring forest cover, identification of drivers of deforestation and developing forest reference emission levels. Forest cover data products with global coverage like GlobeLand30 (Chen et al. 2015), the Global Tree Canopy Cover (Hansen et al. 2013), the JAXA ALOS-PALSAR forest/non-forest map (Shimada et al. 2014), and the Landsat Vegetation Continuous Fields (Sexton et al. 2013) could provide relevant secondary data for study and analysis (Estoque et al. 2018). Various geospatial modeling techniques used with these datasets can provide understanding of complex process of forest cover change, identification of the determinants/drivers of the change and projecting future scenarios (Thapa et al. 2013). Spatial modeling methods, logistic regression (Chowdhury 2006; Echeverria et al. 2008), genetic algorithm (Soares-Filho et al. 2013; Venema et al. 2005), weight of evidence (Maeda et al. 2011; Soares-Filho et al. 2010; Thapa et al. 2013), and artificial neural network (Khoi and Murayama 2011; Mas et al. 2004) have been used in the recent past to study complex process of forest change and associated biophysical and socioeconomic drivers of deforestation. One of the prominent methods includes Cellular automata (CA) with the weights of evidence (WofE) modeling framework that is based on Bayes' rule of probability with an assumption of conditional independence (Thapa 2012). It identifies the 
interaction between changes in forest cover and the various drivers such as physiography, socioeconomic factors, forest management and developmental policies. It has been widely used for modeling changes in land use and land cover (Bonham-Carter 1994).

Being high on deforestation rates (i.e., 1.8\% for 2010-2015), Myanmar has significant prospects to develop conservation strategies and to study biophysical and socioeconomic drivers of forest change at local level (FAO 2010). Case studies of forest change in the country can be helpful for gaining an understanding of complex relationships between social and natural systems that drive landscape change, which is not previously done in the context of Myanmar. Therefore, in this research, we aim to study the forest cover changes and develop a method to examine the underlying drivers of deforestation in Taunggyi District of Shan State, Myanmar. Emphasis has been laid in spatial analysis of forest changes and examination of spatially explicit drivers of deforestation. In addition, future forest cover has been projected under Business As Usual (BAU) scenario for informed prevention awareness for forest management. Readily available global land cover maps were assessed; the one with highest comparative accuracy was used for the study. We employed CA model based on WofE framework to quantify the significant drivers of change and produce future trajectory projection which has the potential to be applied to other parts of the region and upscaled to country level to produce broader results, and will be useful in the study of deforestation trends, policy framing and forest management.

\section{Study area}

Taunggyi is a district located in the Southern Shan State of Myanmar (Fig. 1). The district covers an area of $24,239.10 \mathrm{~km}^{2}$ extending from $96^{\circ} 9^{\prime} 46^{\prime \prime} \mathrm{E}, 22^{\circ} 14^{\prime} 45^{\prime \prime} \mathrm{N}$ to $97^{\circ} 30^{\prime} 38^{\prime \prime} \mathrm{E}$, $19^{\circ} 19^{\prime} 3^{\prime \prime} \mathrm{N}$. The district is home for 1.7 million people where $27.3 \%$ of population living in urban areas (Ministry of Immigration and Population 2015). Physiographically, the district is a part of Shan Plateau that ranges between 100 and $2500 \mathrm{~m}$. The topography is divided into Shan Plateau, Myelat and Plains. Myelat and Plains cover $25 \%$ of the district, and the rest are high plateau with mountain ranges, hills and spurs. Plains cover Kalaw Township, Nyaungshwe and Hopone Townships. Ywangan, Pindaya and Pinlaung Townships are Myelat region, and the rest are Shan Plateau. Mountain ranges lie from north to south in Taunggyi District, and the rivers and streams also flow in the same direction. The forest type identified in the district was Moist Upper Mixed Deciduous Forest, Dry Upper Mixed Deciduous Forest, Evergreen Forest, Dry Hill forest, Indaing forest and Pine forest. As per land use status of the district in 1996 there are 18 Reserve Forest covering an area of $30.12 \%$ of the district followed by 11 protected public forests $(2.98 \%), 11$ protected area system $(5.19 \%)$ and 12 unclass forest $(19.60 \%$ ) in the district (MONREC 2016). Forests in Taunggyi comprise some of tree species with high commercial importance such as Tectona grandis, Dalbergia cultrata, Shorea obtuse, also IUCN "near threatened species" of Dipterocarpus tuberculatus found in the open and dry forests in the district that is mainly being used for firewood purpose by the locals (Field survey, December 2017). 


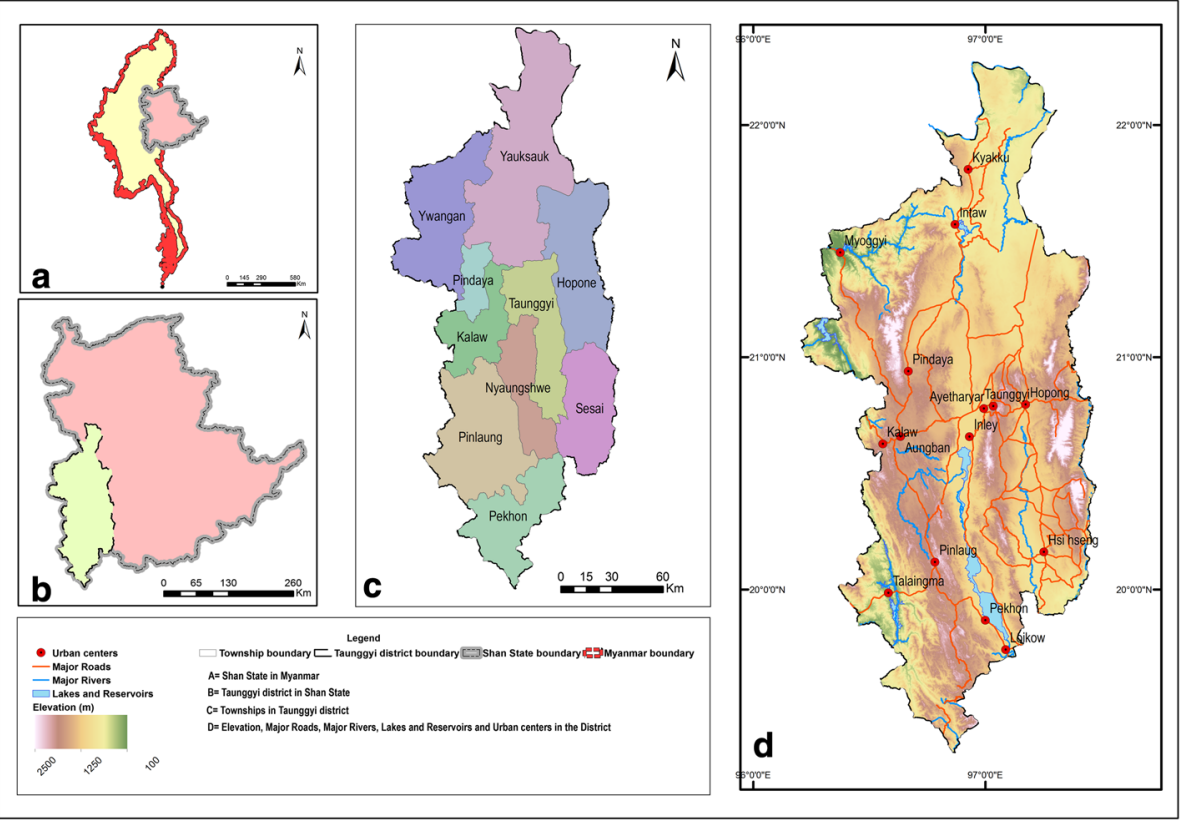

Fig. 1 Study area: Taunggyi District

\section{Methodology}

\subsection{Assessment of land cover data}

We accessed and compared three different land cover maps for the study area. These maps included land cover map provided by Japan Aerospace Exploration Agency (JAXA), forest-non-forest (FNF), SERVIR-Mekong regional land cover map (RLCM) and European Space Agency (ESA) Climate Change Initiative (CCI) for the year 2016. We reclassified these maps into forest and non-forest. As these maps are in different spatial resolutions, we have resampled them at $30 \mathrm{~m}$ for the assessment. For the preparation of reference data, 4000 random sample points at $99 \%$ confidence interval with $2 \%$ error margin were generated across the spatial extent of Taunggyi District. These points were then classified into the forest or non-forest category through inspection in Google Earth Pro. We used the 2016 image in Google Earth to categorize our reference points and used the image of the closest year in case of non-availability of image for the same year. JAXA FNF map depicted 78\% overall accuracy which was highest as compared to $70 \%$ and $66 \%$ overall accuracy of ESA CCI Global land cover map and SERVIR-Mekong RLCM map.

\subsection{Determining deforestation driver variables}

For modeling deforestation trends, it is important to select best set of input variables in order to produce the most optimum fit between the empirical data and observed reality. Therefore, we identified a set of explanatory variables governing the changes from forest 
area to non-forest, for calibrating deforestation model and quantifying drivers leading to deforestation. Given this, it must be noted that there are no universal explanatory factors required for producing ideal simulation results and the set of variables used may not necessarily represent all the factors responsible for the event. The variables may differ from one landscape to another but similar factors found in many studies conducted by Thapa et al. (2013), Carodenuto et al. (2015), Chowdhury (2006), Kolb et al. (2013), Seto and Kaufmann (2003), Thapa et al. (2013), Elz et al. (2015), etc. We examined factors such as elevation, slope, proximity to previously deforested area, proximity to roads, proximity to waterways, proximity to newly constructed reservoirs, proximity to settlements and local-level population density (Table 1). Physical conditions such as elevation, slopes and rivers play an important role in land use changes. Elevation differences promote terrain differences that are associated with complete or selective clearance of forest in Myanmar. Flat land promotes clearance of forest for agricultural needs, while higher elevations associated with rugged topography in most cases make it difficult for clearance of forest stands, especially in the study area. Regions of 100-300 m altitude in this region are often associated with shifting cultivation and conversion of forest land to rubber and palm oil plantation (Myint 2018; Miettinen et al. 2014). Some slopes are subjected to waterlogged conditions, whereas others provide ideal drainage favoring cultivation in turn contributing to forest clearance as part of agricultural expansion. Construction of roads has opened up many intact forests for settlement and resource extraction mostly in the tropical areas. According to the study by Alves 2002, 90\% of deforestation in Amazonian forest occurred within $100 \mathrm{~km}$ of road. Myanmar has been increasing its road network given, the various development projects, growth in foreign trade and population density. Most of the roads being constructed since 2005 in Myanmar tend to be linked with areas of new rubber plantations, mines and hydroelectric project sites built at the cost of forested areas, especially in states of Kachin and Shan. The further expansion in road network is projected to have adverse effect on forest, especially the ones being constructed around heavily forested border areas (UN REDD 2017). Hence, proximity to roads is an important determinant that encourages deforestation arising from higher human accessibility and chances of forest encroachment. Waterways of all forms like navigable rivers, streams and canals have positive correlation with deforestation. According to another study by Barber et al. (2014), nearly $95 \%$ of all deforestation in Brazilian Amazon occurred within $5.5 \mathrm{~km}$ of roads or $1 \mathrm{~km}$ of river. Waterways are largely used for the transportation of logged materials hence forested river banks in tropical areas are highly favorable for tree-felling activities. Construction of canals and related

Table 1 Landscape variables used in the study

\begin{tabular}{ll}
\hline Variable & Source \\
\hline Elevation & SRTM digital elevation model (DEM) (Farr et al. 2007) \\
Slope & Extracted using SRTM DEM \\
Proximity to previously deforested area & Extracted using JAXA FNF map (Shimada et al. 2014) \\
Proximity to roads & Extracted from digitized layer from Google Earth and \\
& MONREC \\
Proximity to waterways & Extracted from digitized layer from Google Earth \\
Proximity to newly constructed reservoirs & Extracted from digitized layer from Google Earth \\
Proximity to settlement & Extracted using data from MONREC \\
Population density & UN-adjusted population density (CIESIN-Columbia 2016) \\
\hline
\end{tabular}


anthropogenic activities in the forested regions lead to deforestation and threaten the biodiversity of the region. As the population of Myanmar grows by approximately $1.5 \%$ annually, with fuel wood and charcoal consumption being $76.41 \%$ of total energy consumption in Myanmar, higher population density would directly put higher pressure on available land resources for food and livelihood opportunities (Sein et al. 2015). Hence, population density of the region is an important driver of deforestation.

Model calibration and simulation were done in Dinamica EGO software that uses Markov chain approach for calculating landscape transition matrices between the years (https://csr.ufmg.br/dinamica/). The effects of the spatial factors on the landscape change and probability map of deforestation for those factors were calculated using the WofE method which is based on Bayesian probability theory. It takes into consideration the deferential effect of spatial factors for predicting deforestation (Soares-Filho et al. 2010). The WofE values represent the attraction or repulsion of deforestation (event) based on the effect of the driving factor to deforestation. Higher values of WofE (greater than 0) depict higher probability of deforestation, whereas negative values represent lower deforestation probability ranges. The variables were tested for spatial dependence using Cramer's V (Bonham-Carter 1994) which shows the values ranging from 0 to 1 depicting the degree of association between the driver factors. Cellular automata (CA) model integrated with WofE was then used to calibrate deforestation pattern across the district and build BAU scenarios for upcoming years.

\subsection{Transition potential map calculation and simulation}

The model was prepared through the standard calibration, simulation and validation method. For calibration, the WofE ranges and the coefficients for each of the driving factors concerning the event, i.e., change of land cover class from non-forest to forest, were calculated. The WofE coefficients calculated through transitional conditional probability are significant in understanding the influence of each these drivers. Due to lack of spatial information on infrastructure development plan, this research assumed that existing infrastructure will be constant and influence equally overtime. Therefore, all of these drivers except proximity to previously deforested area were set static during the model run. The simulation model was then produced by setting internal parameters of patch mean size, variance and isometry. Since the initial year of land cover map used was 2008, the model was iterated 8 times to produce a simulated land cover map of 2016. The model validation included finding change similarity between the observed 2016 and simulated 2016 map using exponential decay function in Dinamica.

\section{Results and discussion}

\subsection{Spatial analysis of forest change}

JAXA forest-non-forest map has been analyzed for the year 2008 and 2016 to study the deforestation over the years. Analyzing the map, it was seen that forest cover in Taunggyi significantly decreased between the years 2008 and 2016 by $1769.28 \mathrm{~km}^{2}$ which is $7.3 \%$ of the forest area. Non-forest category mainly consisting of agriculture, built-up land and tree cover $<10 \%$ has shown an increasing trend from $10,905.83$ to $12,624.17 \mathrm{~km}^{2}$ at the cost of 
Table 2 Area and percentage of land cover

\begin{tabular}{|c|c|c|c|c|c|c|}
\hline \multirow[t]{2}{*}{ Land cover class } & \multicolumn{3}{|c|}{ Land cover area $\left(\mathrm{km}^{2}\right)$} & \multicolumn{3}{|c|}{ Land cover percentage $(\%)$} \\
\hline & 2008 & 2016 & Change (2008-2016) & 2008 & 2016 & Change 2008-2016 \\
\hline Forest & $13,051.58$ & $11,282.3$ & -1769.28 & 53.84 & 46.54 & -7.30 \\
\hline Non-forest & $10,905.83$ & $12,624.17$ & 1718.34 & 44.99 & 52.08 & 7.08 \\
\hline Water & 280.38 & 331.32 & 50.94 & 1.156 & 1.36 & 0.21 \\
\hline
\end{tabular}

forest land over the years. The water category also depicts an increase of $50.94 \mathrm{~km}^{2}$ mainly because of built-up of new artificial reservoirs in this region in the last years (Table 2).

Conversion of land cover from one class to another was also looked upon (Fig. 2). The highest area $\left(3005.84 \mathrm{~km}^{2}\right)$ of inter-land cover class conversion occurred from forest to non-forest. Forest-to-non-forest conversion is observed, particularly in the southern areas of the district. Also, area of $54.27 \mathrm{~km}^{2}$ of forest area is seen to be converted to water, significant portion of it because of the newly constructed reservoirs in the district.

We also analyzed the township-wise change in forest cover in Taunggyi District. The highest change from forest to non-forest category is seen in the township of Pinlaung where forest decreased by $893.345 \mathrm{~km}^{2}$ at the same time non-forest type has increased to a significant amount (Table 3). The water category has also increased by a significant amount compared to 2008 year mainly accounting to construction of artificial reservoirs in the district. Reservoir in Thabyegon (Pinlaung Township) has resulted in the clearing of $63.50 \mathrm{~km}^{2}$ of forest area. Townships of Pekhon, Sesai, Ywangan and Kalaw have observed a striking decrease in forest area over the years. Township of Hopone and Yaksauk surprisingly shows an increasing trend of forest cover and could be an indicator of good forest practices at least at the regional level. Hence, expansion of non-forest areas which mainly consist of agricultural land, urban settlement and barren land have been encroaching fast into the forest areas. Construction of new infrastructure such as reservoirs, dams and road network is also important reason behind such high decline of forest cover in the region.

At national scale, the deforestation trends are alarming. The net loss of forest in Myanmar was reported to be $546 \mathrm{~K}_{\text {ha }}$ year $^{-1}$ between 2010 and 2015 which was $25 \%$ higher than in the 1990s (FAO 2015). Myanmar has undergone agricultural expansion for growing edible crops like rice, fruits, pulses, etc., and plantation of palm oil and rubber which has been responsible for about 1 million ha of forest loss between 2002 and 2014 (UN REDD 2017). The deforestation rate of Myanmar has been ranked second among the southeastasian countries after Indonesia (684 K ha year ${ }^{-1}$ ) and third in the world. In Indonesia, much of the forested land has been converted to palm oil plantation. Evidence shows that $63 \%$ of new palm oil in the country has come at the expense of loss of biodiversity-rich tropical forest between 1990 and 2010. On the other hand, several countries of South and Southeast Asia have shown increasing forest trends for the year 2010-2015. The annual rate of forest gain has been 3.3\%,0.9\%, 0.8\% and 0.3\% in Philippines, Vietnam, China and India that are included in the top 10 counties with highest net forest gain (FAO 2015).

\subsection{Spatial analysis of deforestation drivers}

The WofE coefficients for each of the 8 variables were derived, where the positive coefficients relate to probability of transition potential favoring deforestation, while the 




Fig. 2 Land cover conversion between 2008 and 2016

negative coefficients indicate that the corresponding variables have potential to repel deforestation at those value ranges. Table 4 shows the positive coefficients of the 8 variables and their ranges in descending order. The highest WofE coefficient of drivers variable being distance from the newly constructed reservoirs and could be labeled as 
Table 3 Township-wise area and percentage of land cover

\begin{tabular}{lcccc}
\hline Townships & Total area $\left(\mathrm{km}^{2}\right)$ & \multicolumn{3}{l}{$\begin{array}{l}\text { Percentage of land cover change } \\
(\%)\end{array}$} \\
\cline { 3 - 5 } & & Forest & Non-forest & Water \\
\hline Pinlaung & 3395.73 & -26.31 & 24.44 & 1.87 \\
Pekhon & 2115.01 & -15.56 & 15.85 & -0.29 \\
Sesai & 2079.12 & -13.88 & 13.90 & -0.02 \\
Kalaw & 1449.40 & -9.43 & 9.42 & 0.02 \\
Pindaya & 629.56 & -6.94 & 6.94 & 0.00 \\
Nyaungshwe & 1467.49 & -6.79 & 6.93 & -0.14 \\
Ywangan & 2992.38 & -5.28 & 5.15 & 0.13 \\
Yauksauk & 5152.03 & 0.34 & -0.28 & -0.06 \\
Taunggyi & 2022.58 & 0.37 & -0.11 & -0.25 \\
Hopone & 2935.09 & 5.27 & -5.28 & 0.01 \\
\hline
\end{tabular}

Table 4 Weight of evidence of driver variables

\begin{tabular}{lll}
\hline Variable and unit & Ranges & $\begin{array}{l}\text { Weight of } \\
\text { evidence } \\
\text { coefficients }^{\mathrm{a}}\end{array}$ \\
\hline Proximity to reservoirs (m) & $0 \leq v<100$ & 2.61 \\
Elevation (m) & $0 \leq v<100$ & 2.25 \\
Population density & $220 \leq v<240$ & 1.31 \\
Proximity to non-forest (m) & $0 \leq v<250$ & 0.95 \\
Slope $\left({ }^{\circ}\right)$ & $40 \leq v<60$ & 0.6 \\
Proximity to existing settlement (m) & $0 \leq v<100$ & 0.50 \\
Proximity to existing roads $(\mathrm{m})$ & $0 \leq v<50$ & 0.10 \\
Proximity to existing waterways $(\mathrm{m})$ & $500 \leq v<950$ & 0.015 \\
\hline
\end{tabular}

$v$ Variables evaluated

${ }^{\text {a }}$ Significant at $95 \%$ confidence interval

the driver with the highest impact according to the model. The lowest coefficients are attained by the variables proximity to existing waterways implying the least impact of waterways on deforestation as compared to other factors (Table 4).

It is evident from the derived coefficients that these geophysical and socioeconomics drivers of change do have significance on observed deforestation over the concerned years. If we look at each of these variables separately, it is easier to notice the WofE at their particular ranges. It is clear from Fig. 3 that different factors have varying amounts of effect on deforestation in either promoting or repelling it at different range intervals. The peaks (positive values) depict deforestation potential, whereas the lows (negative values) show ranges that defy deforestation for each variable. Evaluating the drivers of deforestation, it was found that some drivers like agricultural expansion, infrastructural development and fuelwood consumption, forest fires, etc., have direct effect on deforestation. Other drivers that relate to social, cultural or technologies factors like population growth, poverty and policy barriers have indirect effect on forest loss. 

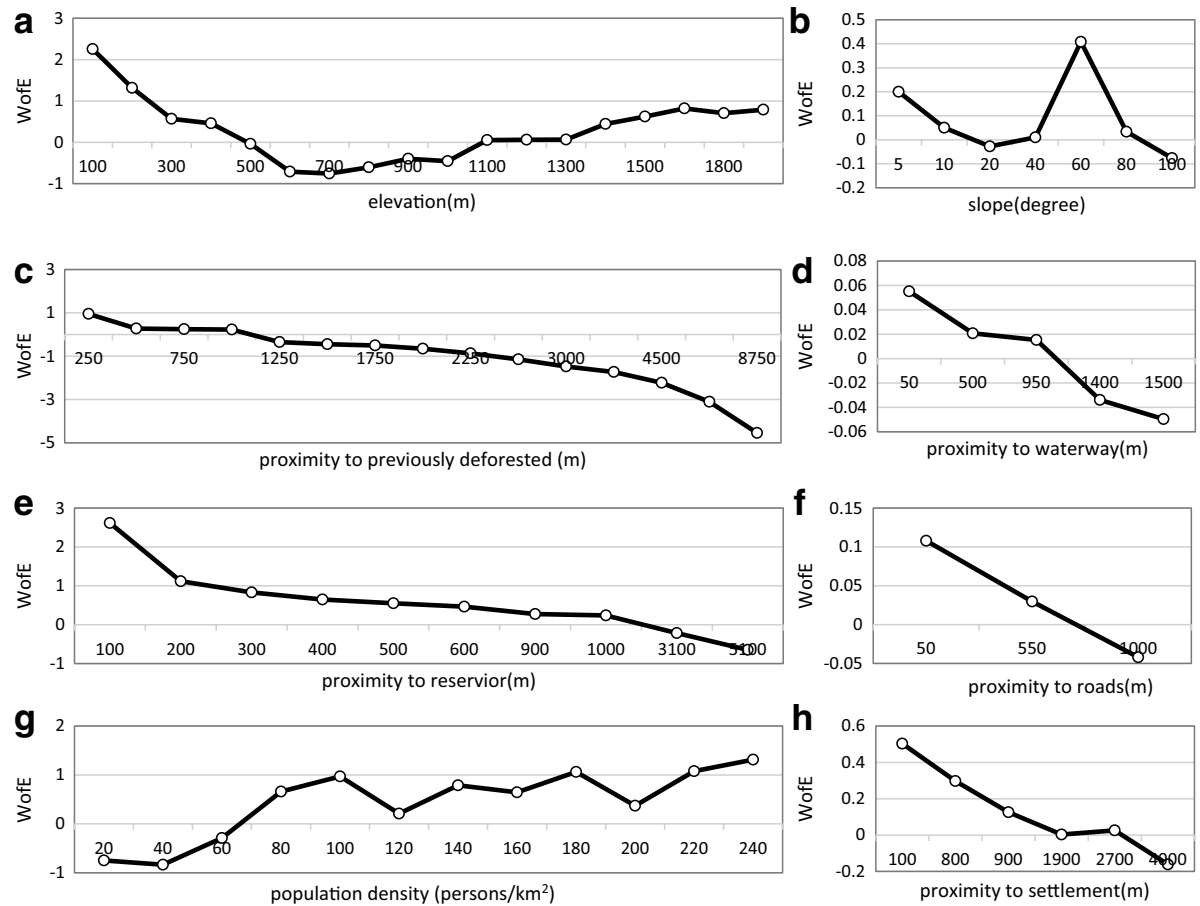

Fig. 3 Weight of evidence coefficients plotted along their range of a elevation, $\mathbf{b}$ slope, $\mathbf{c}$ proximity to previously deforested, $\mathbf{d}$ proximity to waterway, e proximity to reservoir and $\mathbf{f}$ proximity to settlement

In the case of elevation (Fig. 3a) factor, there has been a significant evidence of deforestation in the altitude of 100-200 m ranges with high coefficient of 2.25 . This range is associated with lowland depicting relatively flatter areas in Taunggyi ideal for cultivation, drained by waterways and has been observed to be used for development of hydropower projects. The weight then decreases midway between 500 and $1000 \mathrm{~m}$ elevation with again a steady increase of up to coefficient of 0.78 at $2500 \mathrm{~m}$ elevation. This implies that an increase in deforestation has been observed at elevation greater than $1000 \mathrm{~m}$ and could be a result of forest fragmentation due to shifting cultivation, soil erosion and forest degradation affecting mostly higher altitude of Taunggyi. In Shan State, one of the major causes of deforestation is shifting cultivation or slash and burn farming, traditionally known as "taungya" which has been practiced by ethnic minorities or a long time in hilly areas (Myint 2018).

The slope factor (Fig. 3b) pointed out deforestation to be active at slope range less than 5 degree depicting most of the flat areas of the regions. This major portion of townships of Taunggyi, Sesai and Yauksauk form ideal agricultural tracts that are constantly cleared to expand the existing cultivable land. On the other hand, in the regions hilly terrain small landholdings and population growth force farmers to overexploit the natural resources cutting more trees for fuelwood and clearing land on steep slopes for cultivation (Myint 2018). The probability of deforestation is calculated to be highest (0.6) at $60^{\circ}$ slope. Traditional practice of shifting cultivation is mainly operative in the steeper slopes of the region. This practice is now being replaced by opium cultivation 
and rubber cultivation and commercial growth of such crops are related to low levels of development and higher risk to environmental challenges (Myint 2018; UNODC 2017). Natural or human-induced landslides and forest fires are also important factors for forest loss on steep slopes.

Non-forest area mostly consists of agricultural land, urban centers and other land not covered by forest. Regions in proximity to non-forest areas (Fig. 3c) have shown high probability of deforestation, which decreases as the distance increases. The highest weight of 0.95 is nearest to distance of $250 \mathrm{~m}$ to non-forest land. Hence, expansion of agriculture over the years could be a cause of deforestation prevalent up to distance of $500 \mathrm{~m}$ after which it then gradually repels deforestation. It is generally a notion to clear the surrounding forest fringe for expansion of its existing agricultural land to feed the growing population. Most of the forested land in flatter regions of Taunggyi district is lost because of its conversion to cropland, mainly rice and maize. Many parts of the hilly regions in country have recently undertaken large-scale rubber plantation. There has been a significant increase in area covered by rubber plantation in Shan State from 4000 to 74,200 ha between 2004 and 2005. The southern region of state (Taunggyi District) is characterized by shifting cultivation making forest cover highly dynamic. It is estimated that 15,000 ha of forest in the country is affected each year due to shifting cultivation. These have been an important factor in the increase in non-forested area in the region (UN REDD 2017).

Infrastructural development that includes the construction of reservoirs and artificial waterways, roads and built-up areas has been on rise in the recent years. Myanmar has the largest potential for hydropower development in Southeast Asia. Owing to this, many hydropower projects have been constructed in the country at the expense of forest and more so within reserved forest and protected forest (UN REDD 2017). It was reported that $110,777 \mathrm{~m}^{3}$ of timber was cleared for hydropower development between 2011 and 2012 (Woods 2015). The factor proximity to the reservoirs (Fig. 3e) shows high coefficient values until $900 \mathrm{~m}$ of distance from these newly built infrastructures. The positive WofE coefficient in the vicinity of the reservoirs is because of construction of a reservoir in area previously occupied by forest. This factor can be clearly observed in the case of Taunggyi District where the construction of reservoir at certain location has disturbed existing forest. Other commercial land use projects and infrastructural development such as mining and transportation development through forested areas have adverse effect on the forest health and in majority of the times result in forest loss. Proximity to waterways (Fig. 3d) would mean clearance of forest in river banks and easy transportation of logged materials through navigable rivers. It also relates to canals and other water channels which are built connecting reservoirs/rivers to agricultural land mostly through the forested areas whose construction is related to deforestation. Through the model calibration, deforestation has been observed up to a distance of $950 \mathrm{~m}$ from the waterway quantified by the WofE 0.015. Similarly, construction of roads in heavy forested regions of Myanmar is proven as one of the direct drivers of deforestation. It is the result of infrastructural extension, resource extraction, agricultural expansion and providing accessibility to settlement. Construction of highways and major roads (Fig. 3f) is observed to be promoting deforestation up to a distance of $550 \mathrm{~m}$ up until $1 \mathrm{~km}$. Analyzing the effect of the proximity to settlement (Fig. 3h) has also proved that deforestation is observed in areas closer to settlements. This is one of the direct drivers of deforestation arising from expansion of urban built-up and increased settlement in rural areas. Myanmar has undergone rapid growth in urban and peri-urban settlement since the last decade, and its built-up areas have increased by $24 \%$ from 1992 to 2010 , surely at the expense of its forest. Urban settlement increases risk of deforestation of nearby forest for extension of built-up areas and agricultural land. On the other hand, the 
increase in rural settlement areas would mean higher fuelwood dependency to nearby forest, leading to greater deforestation and forest degradation rates (Sein et al. 2015).

Population density (Fig. 3g) evaluated at an equal interval of 20 persons $/ \mathrm{km}^{2}$ showed high degree of deforestation at density greater than 100 persons $/ \mathrm{km}^{2}$ population density. It got highest at population density of 240 person $/ \mathrm{km}^{2}$ showing higher population density areas evidencing higher deforestation event. In order to meet the demand of growing population, large amount of forest land is under stress. Population growth in most cities like Nay Pi Taw, Yangon and Taunggyi has increased pressure on existing forested land for expansion of infrastructure and meeting agricultural needs. A large portion of rural, peri-urban and urban population is dependent on forest for their daily fuel consumption. Almost $60 \%$ of the population in the country still rely on forest for fuelwood needs, exerting pressure on forest resources. The average annual consumption of fuelwood per household is estimated to be 2.5 cubic tons. With the population projected to increase from 53.9 million in 2015 to 60.2 million by 2030 , consumption of fuelwood and charcoal is projected to increase to 55 million $\mathrm{m}^{3}$ by 2030 leading to higher deforestation and forest degradation rates in the country (UN REDD 2017).

The simulation model produces yearly landscape and probability maps for the given number of years. The landscape changes every year with the transition probability calculated for each year. The forest areas with high probability value have a higher chance of being deforested in the landscape map of simultaneous iterative year. The model can be run $\mathrm{n}$ number of times to produce result of landscape for the $n$th year. Therefore, to produce the simulated landscape 2016 map, the model was iterated 8 times based on the probability of transition for those many years. The spatial independency of the input factor maps was tested using Cramer's (Bonham-Carter 1994). This test shows the degree of association among the factors examined being full or independent ranging from values 0 to 1 , respectively. No significant spatial dependency was detected, and the Cramer's was less than 0.25 in all comparison cases.

\subsection{Model validation}

Validation of a land change model is usually carried out to determine the prediction ability of the model by comparing the predicted result to the reference map. Spatial models are generally validated in the neighborhood context because maps may not always match pixel by pixel, but they may present similar spatial patterns and spatial agreement within a certain cell vicinity (Thapa et al. 2013). We used a two-way reciprocal fuzzy similarity method (Almeida et al. 2008) in which the similarity between two maps is considered based on the influence of the cell and also, to some extent, by its neighbor cell. We compared the spatial similarity between the reference map 2016 and the simulated map 2016 at different scales. The exponential decay function was used to incorporate fuzzy similarity method to validate the prediction power of the model. Since it is a two-way reciprocal fuzzy similarity method, the function compares the differences between the model generated changes in landscapes and the reference (observed) changes in landscapes.

The similarity of the landscape change is $55 \%$ at pixel level and increases to $75.90 \%$ at $9 * 9$ window (Fig. 4). The window size is further increased to reach a similarity fitness of $87.79 \%$ at $21 * 21$ window size. The input land cover resolution was $30 \mathrm{~m}$ and the window size $21 * 21$ pixels, so spatial resolution was $630 \mathrm{~m}$.

It is seen that with the increasing window size, the similarity between the maps also increases meaning that the model can predict spatial patterns more accurately at coarser 
Fig. 4 Spatial similarity between reference map 2016 and simulated map 2016 at different scales

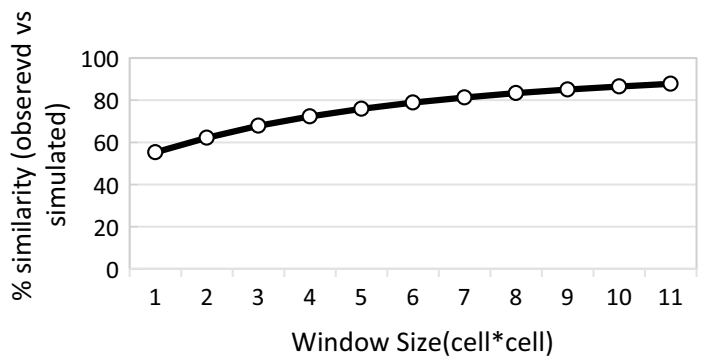

spatial resolution. The model users may select the model in different spatial resolution depending on their scale requirement (Thapa et al. 2013). For example, regional level planners would require much more detailed results than the province level planners and could therefore opt for finer resolution results. Since the model depicts fairly accurate level of compatibility between real and simulated landscapes, it has been further used to develop a simulation model to depict future forest cover scenarios.

\subsection{Forest cover projection}

It is also possible to project the forest cover scenarios to future using the historical trend as part of the simulation model. Figure 5 shows the trend of forest cover for the observed year 2016 and simulated years 2020, 2025 and 2030.

Under BAU scenario, the forest area decreased to striking $33.72 \%$ in 2030 as compared to $46.54 \%$ in 2016 . This decline of $13.72 \%\left(3349.84 \mathrm{~km}^{2}\right)$ in forest cover is the result of continuous operation of driving factors and rate of deforestation. From the total forest loss that occurred between 2016 and 2030, high deforestation tends to affect southern townships of Taunggyi. A closer look into the areas affected by deforestation in each of the 5-year intervals 2020, 2025 and 2030 gives an idea of potential of forest loss in that period in a greater detail (Fig. 6).

In the township-wise analysis of future forest loss scenarios (Fig. 7), it was projected that $35 \%$ of forest loss has taken place in Pinlaung followed by Hopone (12\%), Sesai (11\%), Nyaungshwe (10\%) and Pekhon (10\%). Deforestation tends to affect the southern townships of Taunggyi since these are the areas where the drivers are most actively operating. The townships ranked highest to lowest in the case area of forest loss in the projection

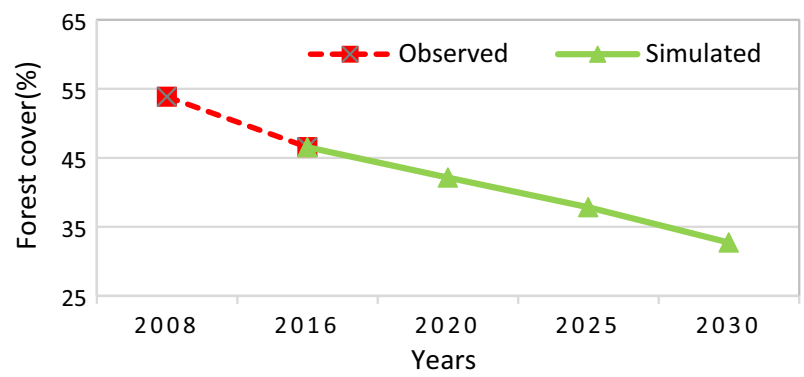

Fig. 5 Trend in area of forest and non-forest during years 2016-2030 


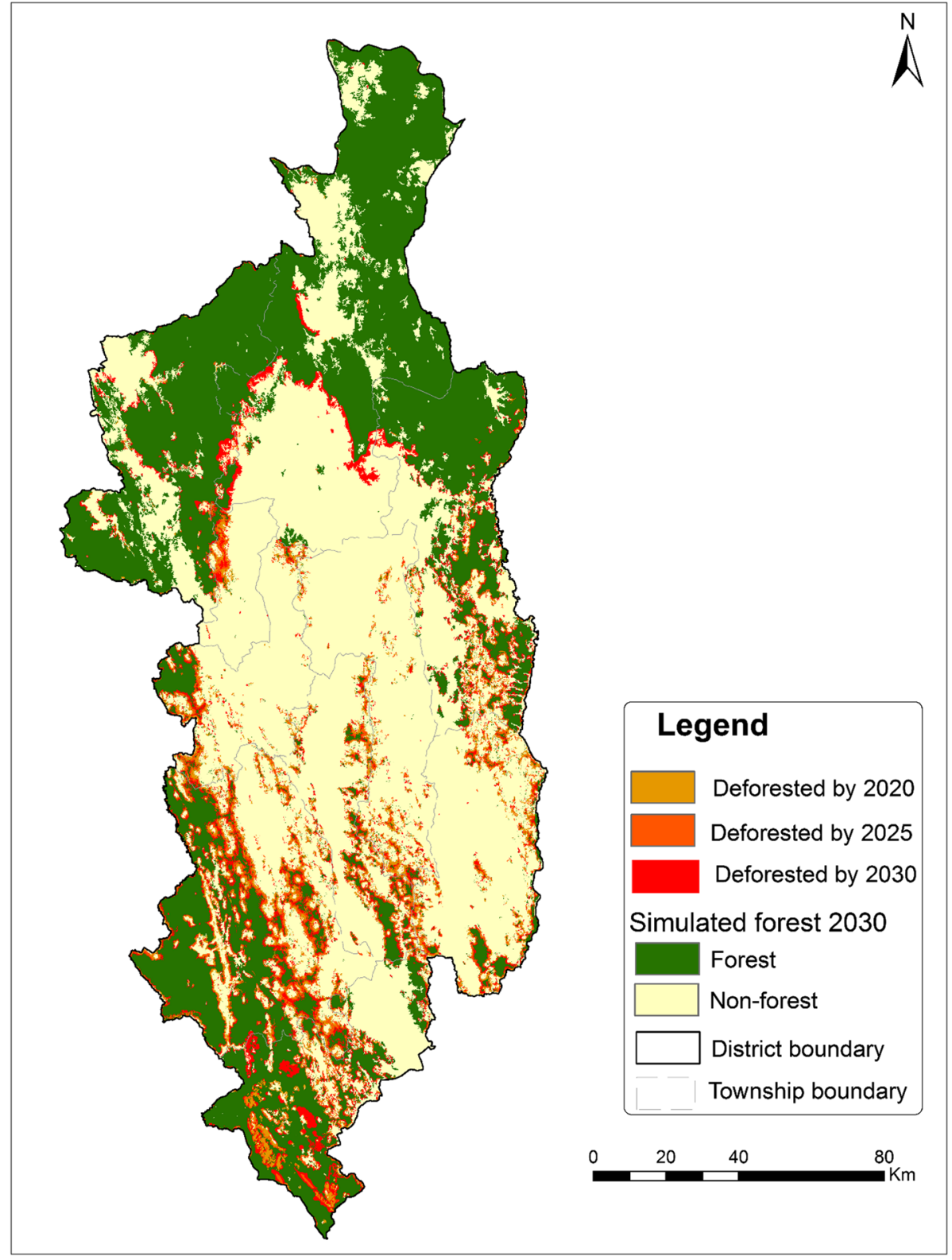

Fig. 6 Forest loss for years 2020, 2025 and 2030

years 2016-2030 remains the same as the observed year 2008-2016 and except the township of Hopone. Hopone Township which did not experience any significant forest loss in observed years 2008-2016 has been projected to lose $277.184 \mathrm{~km}^{2}$ of forest by 2030 .

This could be because of higher proximity to previously deforested land (non-forest in first iteration) owing to highly fragmented landscape in the township. The driver proximity 


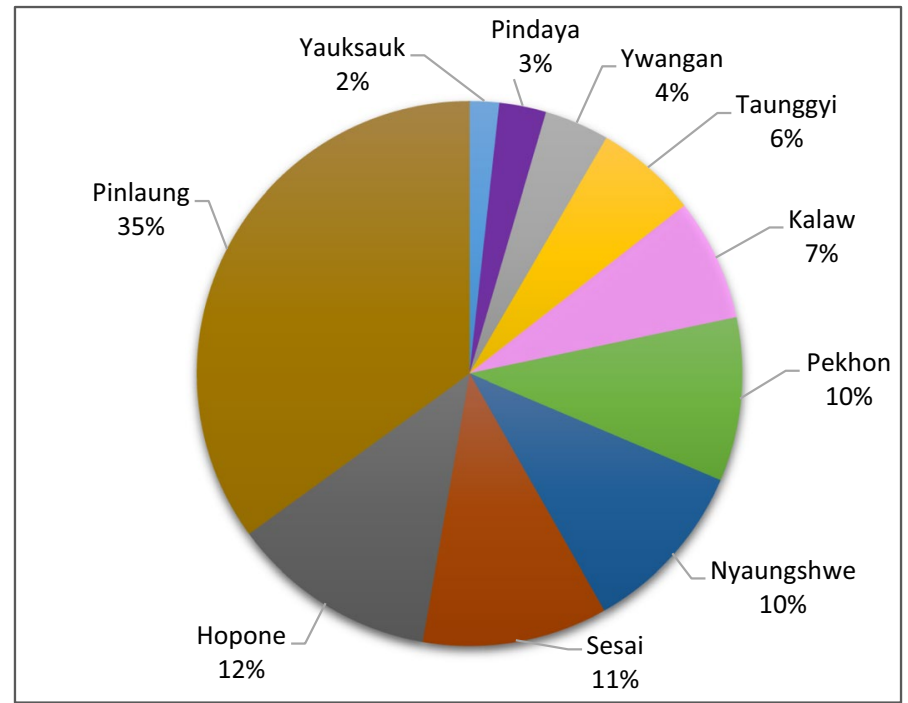

Fig. 7 Township-wise percentage of forest loss 2016-2030

to previously deforested area seems to be operating with high weightage in Hopone Township with high probability of deforestation in the township. The northern most township of Yauksauk accounts for least amount of forest loss for the simulated years 2016-2030 since this area consists of dense compact forest with little disturbance from human activities like construction of reservoirs and roads, fewer settlement and population density of only 35 persons $/ \mathrm{km}^{2}$. High percentage of deforestation in the district is sure to have longterm effect on biodiversity and regional climate regime. Therefore, it is very important for immediate public and private intervention to conserve the forest and to discontinue the present trend of deforestation.

According to the Nationally Determined Contributions, 2016 (NDC) document of Myanmar, the country formulated several actions relevant to climate change mitigation taking 2030 as the target year. Forest preservation measures and the action area of "environment and natural resources" including REDD+ has been in the priority list of the government (MONREC 2018). Thus, keeping in mind the changes in the forest area and potential drivers causing the changes becomes extremely relevant in determining where to lay focus in the coming years while deciding priority zones and framing action plans.

This study mainly uses the available spatial variables as geophysical drivers of deforestation, but many researches, for example Kolb et al. (2013), used a large number of environmental, biophysical and social variables including landforms, hydrology, ethnicity, migration and socioeconomic status. This requires more number of data from field study, but as Pontius et al. (2008) pointed out that a complex model does not necessarily lead to higher predictive power. Generalized models that are flexible with provision for including increasing complexity are often preferred in planning process. Also, land change models can only provide projections based upon the quality of inputs provided to the model. There may be over- or underestimation of future land change due to fluctuations in the annual land change rates, afforestation programmes or changes in government policy that may impact deforestation rates (Elz et al. 2015; Angelsen and Wertz-Kanounnikoff 2008). In addition, there exist knowledge gaps and absence of data in several areas of work in Myanmar. The extent 
to which agricultural expansion is happening in non-forest areas or leads to the clearance of fairly intact natural forests is unknown (UN REDD 2017). Hence, complete understanding and inclusion of other socioeconomic drivers, geological factors, timber trading policies and forest management practices is important for the development of a more accurate model. Filling in these gaps would significantly help to more confidently develop measures and policies for a national REDD+ strategy.

\section{Conclusion}

The study used readily available JAXA FNF map to analyze the changes in forest cover and presented a simple and easily replicable model to study future changes for Taunggyi District. It was derived that the total forest cover declined from 53.84\% in 2008 to $46.54 \%$ in 2016 and projected to $32.72 \%$ in 2030 in the study area. We quantified factors of deforestation and learnt that construction of new infrastructure like reservoirs, certain elevation levels, slope, population density and distance to previously deforested areas received the highest weights. Spatial probability map of deforestation was also simulated that helped demarcate areas with the highest probability to deforestation. A decline of $13.82 \%$ of forest area is simulated for the years 2016-2030.

Since this paper provides a closer look at the drivers and is one of the unique studies in Myanmar, the amount and quality of geographic data are very limited. This study can provide basis for other researches in the country. It could be of importance to policy makers while formation of baseline study, monitoring of forest and formulation of conservation strategies. As initiative like REDD+ gain momentum, this research can provide for better understanding of current forest loss, rate of deforestation and identification of critical areas to be brought under its effect. Since Myanmar has significant potential to reduce its forest carbon emissions and sustainably manage its forest carbon stocks, it is taking rapid steps in implementing REDD+ readiness phase. Any REDD+ Demonstration Activity in this district will need to enhance the protection of existing national parks, implementation of existing regulations and alternative land use opportunities for locals while addressing key drivers of deforestation.

Acknowledgements This study was conducted with the financial and technical support from International Centre for Integrated Mountain Development (ICIMOD). The study owes a lot to the support it received from ICIMOD's GIZ REDD+ Himalaya initiative for financial aid. We would like to thank Dr. Bhaskar Karky for his kind supervision throughout the course of the research and Mr. Niroj Timalsina and Ms. Shambhavi Basnet for providing assistance in the field and during the research. We are also thankful to Forest Research Institute (FRI), Myanmar, for their support in the field and Dr. Inkyin Khaine (FRI) for providing some of the spatial data of Myanmar.

Disclaimer The views and interpretations in this publication are those of the authors. They are not necessarily attributable to ICIMOD and do not imply the expression of any opinion by ICIMOD concerning the legal status of any country, territory, city or area of its authority, or concerning the delimitation of its frontiers or boundaries, or the endorsement of any product.

Open Access This article is distributed under the terms of the Creative Commons Attribution 4.0 International License (http://creativecommons.org/licenses/by/4.0/), which permits unrestricted use, distribution, and reproduction in any medium, provided you give appropriate credit to the original author(s) and the source, provide a link to the Creative Commons license, and indicate if changes were made. 


\section{References}

Almeida, C. M., Gleriani, J. M., Castejon, E. F., \& Soares-Filho, B. S. (2008). Using neural networks and cellular automata for modelling intra-urban land-use dynamics. International Journal of Geographical Information Science, 22(9), 943-963. https://doi.org/10.1080/13658810701731168.

Alves, D. S. (2002). Space-time dynamics of deforestation in Brazilian Amazônia. International Journal of Remote Sensing. https://doi.org/10.1080/01431160110096791.

Angelsen, A., \& Wertz-Kanounnikoff, S. (2008). Moving ahead with REDD: Issues, options and implications. CIFOR, Bogor, Indonesia.

Barber, C. P., Cochrane, M. A., Souza, C. M., \& Laurance, W. F. (2014). Roads, deforestation, and the mitigating effect of protected areas in the Amazon. Biological Conservation, 177(2014), 203-209. https://doi.org/10.1016/j.biocon.2014.07.004.

Bonham-Carter, F. G. (1994). Geographic information systems for geoscientists: Modelling with GIS. Amsterdam: Elsevier. https://doi.org/10.1016/0098-3004(95)90019-5.

Carodenuto, S., Merger, E., Essomba, E., Panev, M., Pistorius, T., \& Amougou, J. (2015). A methodological framework for assessing agents, proximate drivers and underlying causes of deforestation: Field test results from Southern Cameroon. Forests, 6(1), 203-224. https://doi.org/10.3390/f6010 203.

Chen, J., Chen, J., Liao, A., Cao, X., Chen, L., Chen, X., et al. (2015). Global land cover mapping at $30 \mathrm{~m}$ resolution: A POK-based operational approach. ISPRS Journal of Photogrammetry and Remote Sensing, 103, 7-27. https://doi.org/10.1016/j.isprsjprs.2014.09.002.

Chowdhury, R. R. (2006). Driving forces of tropical deforestation: The role of remote sensing and spatial models. Singapore Journal of Tropical Geography, 27(1), 82-101. https://doi.org/10.111 1/j.1467-9493.2006.00241.x.

CIESIN-Columbia. (2016). Gridded population of the world, version 4 (GPWv4): Population density adjusted to match 2015 revision UN WPP country totals. Palisades, NY: NASA Socioeconomic Data and Applications Center (SEDAC). https://doi.org/10.7927/H4HX19NJ.

Echeverria, C., Coomes, D. A., Hall, M., \& Newton, A. C. (2008). Spatially explicit models to analyze forest loss and fragmentation between 1976 and 2020 in southern Chile. Ecological Modelling, 212(3-4), 439-449. https://doi.org/10.1016/j.ecolmodel.2007.10.045.

Elz, I., Tansey, K., Page, S., \& Trivedi, M. (2015). Modelling deforestation and land cover transitions of tropical peatlands in Sumatra, Indonesia using remote sensed land cover data sets. Land, 4(3), 670687. https://doi.org/10.3390/land4030670.

Estoque, R. C., Pontius, R. G., Murayama, Y., Hou, H., Thapa, R. B., Lasco, R. D., et al. (2018). Simultaneous comparison and assessment of eight remotely sensed maps of Philippine forests. International Journal of Applied Earth Observation and Geoinformation, 67, 123-134. https://doi. org/10.1016/j.jag.2017.10.008.

FAO. (2010). Global forest resources assessment 2010: FAO forestry paper (Vol. 163). http://www.fao. org/3/a-i1757e.pdf. Accessed 28 Oct 2018.

FAO. (2015). Global forest resources assessment 2015: Desk reference. http://www.fao.org/3/a-i4808e.pdf.

Farr, T., Rosen, P., Caro, E., Crippen, R., Duren, R., Hensley, S., et al. (2007). The shuttle radar topography mission. Reviews of Geophysics, 45(2005), 1-33. https://doi.org/10.1029/2005RG000183.

Hansen, M. C., Potapov, P. V., Moore, R., Hancher, M., Turubanova, S. A., Tyukavina, A., et al. (2013). High-resolution global maps of 21st-century forest cover change. Science, 342, 850-853.

IPCC. (2008). Climate change 2007- mitigation of climate change contribution of working group III to the fourth assessment report of IPCC. http://www.ipcc.ch/publications_and_data/.htm. Accessed 28 Oct 2018.

Khoi, D. D., \& Murayama, Y. (2011). Modeling deforestation using a neural network-markov model BT. In Y. Murayama \& R. B. Thapa (Eds.), Spatial analysis and modeling in geographical transformation process: GIS-based applications (pp. 169-190). Dordrecht: Springer. https://doi. org/10.1007/978-94-007-0671-2_11.

Kolb, M., Mas, J.-F., \& Galicia, L. (2013). Evaluating drivers of land-use change and transition potential models in a complex landscape in Southern Mexico. International Journal of Geographical Information Science, 27(9), 1804-1827. https://doi.org/10.1080/13658816.2013.770517.

Maeda, E. E., de Almeida, C. M., de Carvalho Ximenes, A., Formaggio, A. R., Shimabukuro, Y. E., \& Pellikka, P. (2011). Dynamic modeling of forest conversion: Simulation of past and future scenarios of rural activities expansion in the fringes of the Xingu National Park, Brazilian Amazon. International Journal of Applied Earth Observation and Geoinformation, 13(3), 435-446. https:// doi.org/10.1016/j.jag.2010.09.008. 
Mas, J., Puig, H., Palacio, J. L., \& Sosa-López, A. (2004). Modelling deforestation using GIS and artificial neural networks. Environmental Modelling and Software, 19, 461-471.

Miettinen, J., Stibig, H. J., \& Achard, F. (2014). Remote sensing of forest degradation in Southeast AsiaAiming for a regional view through 5-30 m satellite data. Global Ecology and Conservation, 2, 24-36. https://doi.org/10.1016/j.gecco.2014.07.007.

Ministry of Immigration and Population. (2015). The 2014 Myanmar Population and Housing Census. The Union Report: Census Report Volume 2 (Vol. 2). https://data.unhcr.org/thailand/download. php?id=421. Accessed 31 Aug 2018.

MONREC. (2016). District forest management master plan (30 years). Nay Pyi Taw: Forest Department.

MONREC. (2018). Forest reference emission level (FREL) of Myanmar. https://redd.unfccc.int/files/2018_ frel_submission_myanmar.pdf. Accessed 24 Aug 2018.

Myint, A. A. (2018). Analysis of drivers of deforestaton and forest degradation in Shan State and strategic options to address them. Kathmandu: ICIMOD.

Pontius, R. G., Boersma, W., Castella, J. C., Clarke, K., Nijs, T., Dietzel, C., et al. (2008). Comparing the input, output, and validation maps for several models of land change. Annals of Regional Science, 42(1), 11-37. https://doi.org/10.1007/s00168-007-0138-2.

Sein, C. C., Aye, Z. M., \& Razafindrabe, B. H. N. (2015). Study on consumption of fuel wood and its impacts to forest resources in Taungyi District. Global Science Research Journal, 3(2), 43-51.

Seto, K. C., \& Kaufmann, R. K. (2003). Modeling the drivers of urban land use change in the pearl river delta, China: Integrating remote sensing with socioeconomic data. Land Economics, 79(1), 106-121. https://doi.org/10.2307/3147108.

Sexton, J. O., Song, X.-P., Feng, M., Noojipady, P., Anand, A., Huang, C., et al. (2013). Global, 30-m resolution continuous fields of tree cover: Landsat-based rescaling of MODIS vegetation continuous fields with lidar-based estimates of error. International Journal of Digital Earth, 6(5), 427-448. https://doi. org/10.1080/17538947.2013.786146.

Shimada, M., Itoh, T., Motooka, T., Watanabe, M., Shiraishi, T., \& Thapa Rajesh, L. R. (2014). New global forest/non-forest maps from ALOS PALSAR data (2007-2010). Remote Sensing of Environment, 155, 13-31. https://doi.org/10.1016/j.rse.2014.04.014.

Soares-Filho, B., Moutinho, P., Nepstad, D., Anderson, A., Rodrigues, H., Garcia, R., et al. (2010). Role of Brazilian Amazon protected areas in climate change mitigation. Proceedings of the National Academy of Sciences, 107(24), 10821-10826. https://doi.org/10.1073/pnas.0913048107.

Soares-Filho, B. S., Rodrigues, H., \& Follador, M. (2013). A hybrid analytical-heuristic method for calibrating land-use change models. Environmental Modelling and Software, 43, 80-87. https://doi. org/10.1016/j.envsoft.2013.01.010.

Thapa, R. B. (2012). Weight of evidence in geospatial analysis. In Y. Murayama (Ed.), Progress in geospatial analysis. Tokyo: Springer. https://doi.org/10.1007/978-4-431-54000-7_7.

Thapa, R. B., Shimada, M., Watanabe, M., \& Motohka, T. (2013). The tropical forest in south east Asia: Monitoring and scenario modeling using synthetic aperture radar data. Applied Geography, 41, $168-178$.

UN REDD. (2017). Drivers of deforestation and forest degradation. MONREC, REDD+ Myanmar, UN REDD. http://www.myanmar-redd.org/wpcontent/uploads/2017/10/Myanmar-Drivers-Report-final _Eng-Version.pdf. Accessed 19 July 2018.

UNODC. (2017). Evidence for enhancing resilience to opium poppy cultivation in Shan State, Myanmar: Implications for alternative development, peace, and stability. http://www.unodc.org/documents/south eastasiaandpacific//Publications/2017/2016_Myanmar_Shan_Opium_Poppy_web.pdf. Accessed 28 Sept 2018.

Venema, H., Calamai, H., \& Fieguth, P. (2005). Forest structure optimization using evolutionary programming and landscape ecology. European Journal of Operational Research, 164, 423-439. https://doi. org/10.1016/j.ejor.2003.11.011.

Wang, C., \& Myint, S. W. (2016). Environmental concerns of deforestation in Myanmar 2001-2010. Remote Sensing, 8(9), 1-15. https://doi.org/10.3390/rs8090728.

Woods, K. (2015). Commercial agriculture expansion in Myanmar: Links to deforestation, conversion timber, and land conflicts. In Forest trade and finance report series, Forest Trends.

Publisher's Note Springer Nature remains neutral with regard to jurisdictional claims in published maps and institutional affiliations. 